\title{
Study of Geotechnical Properties of Clayey Soils Contaminated by Various Oils
}

\author{
Swati Sukhwal, Pradyumna Dashora \\ Pacific University
}

\begin{abstract}
Swiftly expanding populace everywhere throughout the world is in direct extent to the advancement programmes in lodging and development of modern upgrade. The environment is been tainted by living persons deliberately or non-deliberately for their convenience. During this whole process not only, air and water is being tainted but the land is also been contaminated at large scale. Oil contamination in soil can take place as a result to several reasons such as oil leaking from pipelines that may have cracks or small holes, discharge from alongshore, tanker accidents and shoreside petroleum generation facilities. The main objective of this study is to analyse various laboratory testing program to study the effect of various oil contaminants on the geotechnical properties of place soil. The studied properties included the use of different percentages of heavy oil, diesel and castor oil.
\end{abstract}

Keywords: - Heavy oil, Diesel, Castor oil, Clayey soil.

\section{INTRODUCTION}

In the past few years, populace development, dynamic expectation for everyday comforts and mechanical advancement have prompted air, water and land in a very bad condition. Buried wastes, land disposal, industrial waste and chemical wastes led to many problems.

It is necessary to run industries as it is very helpful for the socio-economic evolution of a country but simultaneously it produces a very large amount of waste.

The modification of the mechanical and physical of the ground in the surrounding of industrial plants arises generally as a outcome of their pollution produced due to dumping of liquid or solid discharge by-product waste over the ground and /or accidental spills of chemical during the process of the source of industrial activities and exercise in pharmaceuticals, petroleum, paints etc. So, soil getting polluted highly effects the grain size of soil sample, specific gravity, plastic limit, hydraulic conductivity compaction and consolidation characteristics and strength properties of soil. The unforeseen variation can head over to numerous geotechnical problems such as progressive failure, underground structure stability, landslides, ground subsidence, settlement. To study the effect of all contamination on Geo technical properties of clay salts, the souls of a contaminated with various orders using different percentages by weight of soil. In this research silty clay, black cotton soil and kaolinite clay was used for the study physical, engineering and electrical properties of the contaminated soil has been studied.

\section{MATERIALS AND METHODS}

The research work was directed with silty clay, black cotton soil and kaolinite clay. Castor oil, heavy oil and diesel were utilised as contaminants. The sawdust was used as a stabiliser during the test. This soil was contaminated in the laboratory with different percentages of various contaminants to study the contaminated effect on different Geotechnical and engineering properties of soil.

TABLE 1. BASIC AND ENGINEERING PROPERTIES OF VIRGIN SOILS

\begin{tabular}{|c|c|c|c|}
\hline Property & $\begin{array}{l}\text { Silty } \\
\text { clay }\end{array}$ & $\begin{array}{l}\text { Black } \\
\text { Cotton }\end{array}$ & $\begin{array}{l}\text { Kaolinite } \\
\text { Clay }\end{array}$ \\
\hline Specific $\quad$ gravity & 2.319 & 2.58 & 2.635 \\
\hline Liquid limit (\%) & 30.00 & 77.14 & 88.88 \\
\hline Plastic limit (\%) & 21.114 & 38.545 & 40.45 \\
\hline $\begin{array}{l}\text { Optimum Moisture } \\
\text { Content }(\%)\end{array}$ & 12.240 & 21.269 & 31.8 \\
\hline $\begin{array}{l}\text { Maximum dry } \\
\text { density }(\mathrm{gm} / \mathrm{cc})\end{array}$ & 1.822 & 1.574 & 1.38 \\
\hline $\begin{array}{l}\text { Unconfined } \\
\text { compressive } \\
\text { strength }\end{array}$ & 0.789 & 1.189 & 2.646 \\
\hline $\begin{array}{l}\text { Modulus of } \\
\text { elasticity }(\mathrm{kg} / \mathrm{cm} 2)\end{array}$ & 30.55 & 85.61 & 46.76 \\
\hline Cohesion $(\mathrm{kg} / \mathrm{cm} 2)$ & 0.398 & 1.416 & 0.99 \\
\hline $\begin{array}{l}\text { Angle of internal } \\
\text { friction }\end{array}$ & 23.350 & 3.03 & 14.630 \\
\hline $\begin{array}{ll}\text { CBR } & \text { value } \\
\text { (Unsoaked) } & \end{array}$ & 24.986 & 17.827 & 17.125 \\
\hline $\begin{array}{ll}\text { CBR } & \text { value } \\
\text { (Soaked) } & \end{array}$ & 11.651 & 3.088 & 1.684 \\
\hline Dielectric constant & 7312 & 568 & 423.2 \\
\hline $\begin{array}{l}\text { Resistivity } \quad(\mathrm{k} \Omega- \\
\mathrm{cm})\end{array}$ & 19.807 & 1077.921 & 787.181 \\
\hline
\end{tabular}




\section{RESULTS AND DISCUSSIONS}

\section{A. Specific Gravity}

The specific gravity of all contaminated soils was noticed to decrease with an increasing percentage of different soils, this was because of the oil fills up the pore spaces of soils which has less specific gravity than the soil.

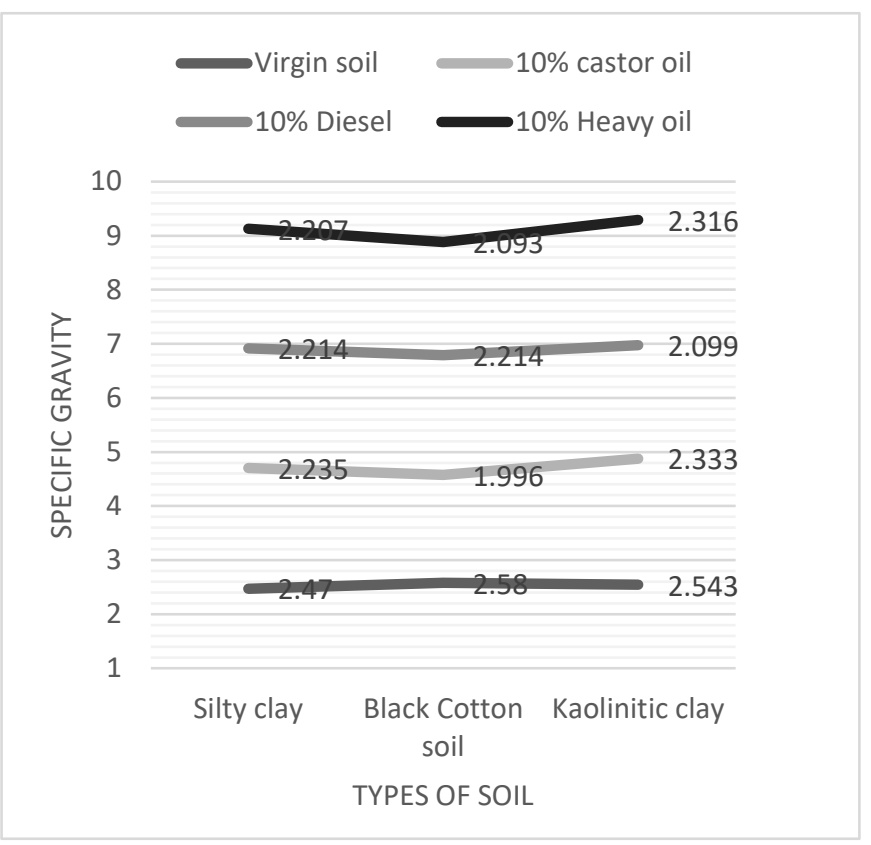

Fig 1 . Specific gravity of various contaminated soil with $10 \%$ contaminants

\section{B. Atterberg Limits}

Depending on its water content, a soil may appear in one of the four states; solid, plastic, semi-solid, limit. The Atterberg limits that are most useful for engineering purpose are; plastic limit and liquid limit. The water content at which the soil changes from one state to the other are called as consistency limits or Atterberg's limits.

1) Liquid Limit: Liquid limit is defined as the minimum water content at which the soil is still in the liquid state, but has very small shearing strength, which can be measured by standard laboratory equipment.

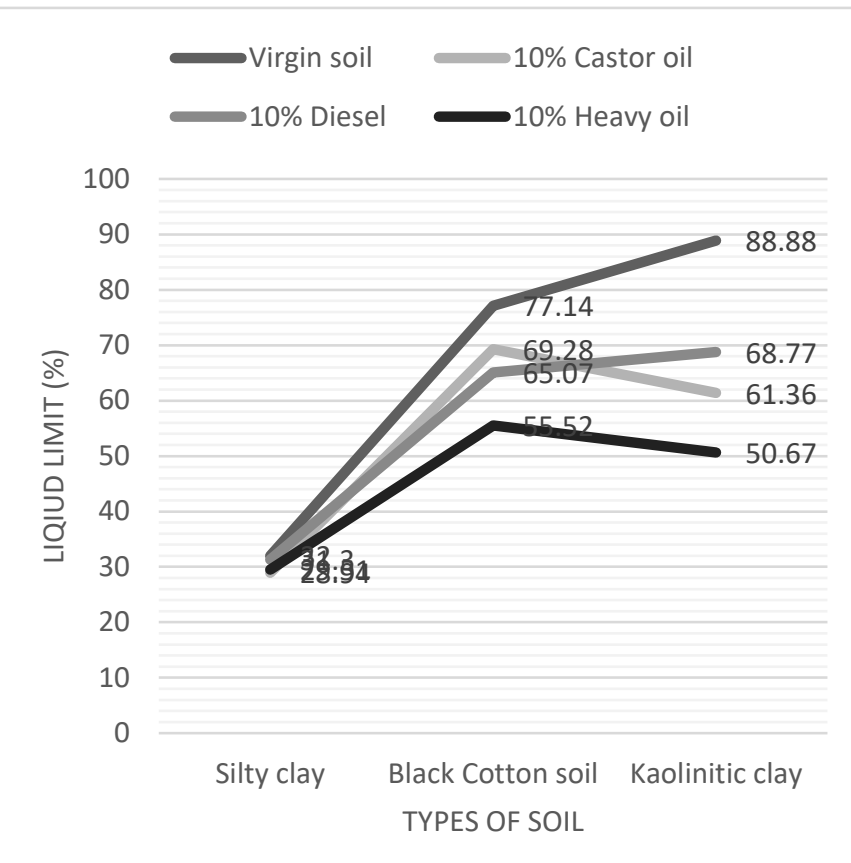

Fig 2. Liquid limit for different contaminated soil with $10 \%$ contaminants

2) Plastic Limit:

Plastic limit is the water content after which the soil discontinued to behave as a plastic material i.e. it starts to tumble down when rolled into a thread of soil of $3 \mathrm{~mm}$ diameter. At this stage of the water content, the soil loses its plasticity and passes to semi- solid state.

\section{Optimum Moisture Content}

The water content at which a soil can be compacted to the maximum dry unit weight by a given comp active effort is called as Optimum water content. It was noticed to get decrease with an increase in the oil contaminant.

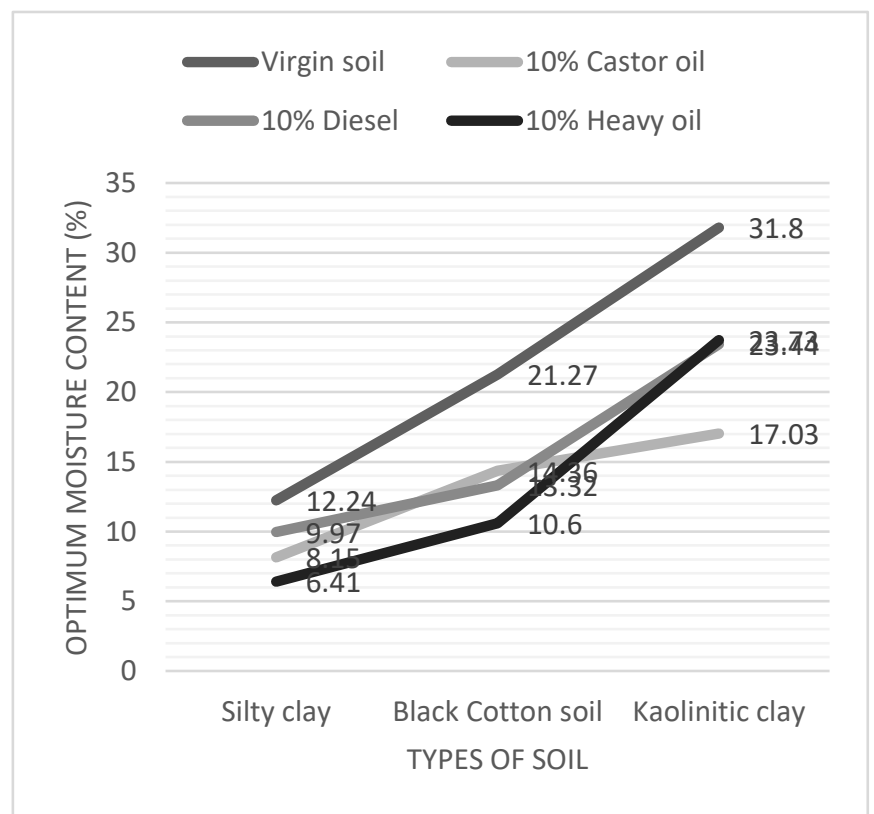

Fig 3 Optimum moisture content of various contaminated soil is the $10 \%$ contaminants 


\section{CONCLUSION}

The research was aimed to study the effect of various oil contaminants on geotechnical properties of clayey soils. It was observed that there was a great change in the geotechnical properties of the soil with an increase in the concentration of oil contaminant. The specific gravity of all contaminated soils was noticed to have a decreasing trend on an increase in the percentage of various oils. The liquid limit of varying contaminated soil with different percentages of contaminants (castor oil, diesel and heavy oil respectively) was observed to decrease as the percentage of contaminants increase. The optimum Moisture content of silty clay and black cotton soil decreased with an increase in a castor oil and heavy oil.

\section{REFERENCE}

[1] Ahmet Tuncan, Mustafa Tuncan and Hakan Koyuncu (May1999) "Use of petroleum-contaminated drilling wastes as sub-base material for road construction" Waste Management and Research.

[2] Charles M Reminds and Brent a Korean " Soil Remediation Demonstration Project: Biodegradation of Heavy Fuel Oils.

[3] Charles M Raymonds, Prasanta Bhunia, Brent A Koenen (August -1997) " Soil Remediation Demonstration Project: Biodegradation of Heavy Fuel Oils".

[4] Habib-ur-Rehman, Sahel-N-Abduljauwad " Geotechnical Behaviour of Oil-contaminant Fine-Grained Soils".

[5] Mohamed Gabr, Brian Kamnikar, Greg Smith " Physiochemical Phenomena in soils".

[6] Mitchell (1993) " Fundamental of Soil Behaviour" Wiley, New York,

[7] P Tiwari, M.K. Gupta and R.K. Srivastava (2006) " Laboratory Studies on Surfactant Enhanced Remediation of Engine Oil Contaminated Soils". 